\title{
Assessment of Soil Quality under two Irrigation Systems in the Sokoto-Rima Basin, Nigeria
}

\author{
Graham WBR* \\ Department of Agricultural Engineering, Waziri Umaru Federal Polytechnic, Nigeria
}

Submission: December 21, 2016; Published: January 23, 2017

"Corresponding author: Graham WBR, Department of Agricultural Engineering, Waziri Umaru Federal Polytechnic, Nigeria, Tel: +234 806668 5208; Email: grayhomestead@gmail.com

\begin{abstract}
Most irrigation projects in Nigeria are presently in a state of disrepair. One principal factor responsible for this is a decline of soil quality (SQ). Two soil quality indices were developed (one, rice based (RSQI) the other, vegetable based (VSQI)) using four soil attributes associated with irrigated agriculture namely; nutrient relations, water relations, soil physical stability/support and salt constraints. The indices were used to evaluate soil quality in the Zauro Polder Pilot Irrigation Scheme (ZPPIS), comparing this scheme to an adjacent area outside this scheme (FS) where non-formal irrigation is practised. With respect to RSQI, the soils of both systems rated good in soil quality with mean total SQ ratings of 0.554 (ZPPIS) and 0.459 (FS). Of the four soil attributes the only significant difference in SQ was with respect to the water relations attribute. On the contrary, when considering the VSQI, the soils of the FS out-performed the soils of the ZPPIS in regards to all soil attributes and the total SQ. With a mean SQ rating of 0.634, the soils of the FS had good SQ while the soils of ZPPIS rated poor in SQ with a mean SQ rating of 0.360 .
\end{abstract}

Keywords: Management of irrigation projects; Soil degradation; Polder irrigation schemes

\section{Introduction}

Irrigation has been seen as a panacea to the problems of food production in drought prone Sokoto-Rima basin (SRB) of northwestern Nigeria. The Food and Agricultural Organization of the United Nations (FAO) in a study of the SRB recommended a relatively modest dam on the Sokoto River as part of a comprehensive basin development plan FAO [1]. This report emphasized the importance of a gradual approach that would have minimal impact on existing land use. Instead a number of large dams and irrigation schemes none of which can be said to successful today have been built. These dams according to Atkins International (2006) are poorly managed and, in many cases, barely operational with little or no maintenance. Frequently designed as "multi-purpose", they often serve almost no purpose with only 10 to 20 percent of the water being effectively utilized.

Ironically, these dams and associated irrigation schemes were developed on Fadama lands that have been traditionally irrigated for centuries using traditional water lifting technologies [2,3]. Fadama is a Hausa word which refers to low lying, relatively flat areas either in streamless depressions or adjacent to seasonally or perennially flowing streams Kolawole \& Scoones [4]. The fadama has been described by Arnborg [5] as 'a garden, a little paradise' in a semi-arid environment. The low lying fadama lands are underlain by extensive aquifers, which are in hydrological contact with the river systems and are easily exploitable through the use of shallow (low cost) tube wells and wash-bores. There are an estimated 4,507 $\mathrm{km}^{2}$ of fadama in the SRB Wardrop Engineering Inc [6]. A host of high value agronomic and horticultural crops are intensively grown due the fadamas sustainability and availability of water all year round and also due to its agricultural superiority to the upland soils.

Kolawole \& Scoones [4] however, described the fadama is probably one of the most endangered environmental resources in northern Nigeria. The fadama is a product of seasonal or almost permanent flooding. When the water has been harvested as in areas that are dammed, the interference with the natural environment creates further modification to the land area affected and the interacting qualities of water and the soil Owonubi et al. [7]. One typical example is the 23,000 ha Bakolori Irrigation Project which Kolawole [8] described as one of the most expensive irrigation schemes in the world. This scheme presently irrigates just 8,000 ha Graham et al. [2] yet its construction submerged about 12, 000 ha of crop fields and a further 11,000ha of downstream cropping was wiped out due to a reduction in the natural flooding of the river Adams [9]. 
The Zauro Polder Project (ZPP) was one of those projects conceived in the 1970's. The project was initially designed to irrigate over 11,000 hectares of land. The design involved the construction of a system of flood protective dykes along the course of the Sokoto-Rima River with canals carrying irrigation water to the farm lands. Prior to achieving this objective, a pilot scheme The Zauro Polder Pilot Irrigation Scheme (ZPPIS) with an area of 100 hectares was initiated in 1982 to be used as a model upon which improvements could be made on some design aspects of the main project Wakuti Consulting Engineers, [10]. Construction of the ZPP was stalled for many years for political reasons and opposition from the beneficiary communities who believe their farms would be submerged and destroyed. This notwithstanding, there are still plans to go ahead with construction.

Soil quality (SQ) is defined as the capacity of the soil to function within ecosystem boundaries to sustain biological productivity, maintain environmental quality, and promote plant and animal health Doran \& Parkin [11]. According to Doran [12], soil quality assessment is an invaluable tool for determining the sustainability of land management systems. A number of procedures have being used in its assessment. These include mathematical methods Doran \& Parkin [11]; Brejda et al. [13]; Li \& Lindstrom [14]; Sun et al. [15]; Shukla et al. [16]; Velasquez et al. [17] and the use of a soil quality index Hussain et al. [18]; Glover et al. [19]; Andrews et al. [20-22]; Masto et al. [23]; Xu et al. [24]; Erkossa et al. [25]; Qi et al. [26].

Indexing soil quality usually involves three steps. The first is selecting appropriate soil quality indicators to efficiently and effectively monitor critical soil functions as determined by the specific management goals for which an evaluation is being made. Each indicator is then scored using critical limits that are related to the soil functions chosen. The indicators are then converted into dimensionless values which are combined into an overall index of soil quality Hussain et al. [18]; Andrews et al. [22]; Xu et al. [24]; Erkossa et al. [25]; Qi et al. [26]; Karlen et al. [27]. This index can be easily modified for different land use systems, environments and soils.

The objective of this paper is to use a SQ index to evaluate the soils of the ZPPIS after 27 years of irrigation and then compare with the adjacent fadama, assuming that the present state of the fadama soils would be similar to original state of the ZPPIS soils before impoundment.

\section{Materials and Methods}

\section{The study area}

The study area lies at approximately an altitude of $200 \mathrm{~m}$ above sea level between latitudes $12^{\circ} 23^{\prime}$ and $12^{\circ} 35^{\prime} \mathrm{N}$ and longitudes $4^{\circ} 08^{\prime}$ and $4^{\circ} 26^{\prime} \mathrm{E}$ in the Sudan Savanna agro-ecological zone of North-western Nigeria (Figure 1). The mean annual rainfall is approximately $650 \mathrm{~mm}$ falling mostly between June and September, with the rest of the year a pronounced dry period. The yearly moisture balance indicates more than $800 \mathrm{~mm}$ deficit above the surplus. The soils in the study area have been classified as Eutric/ Dystric Fluvisols FDALR [28].

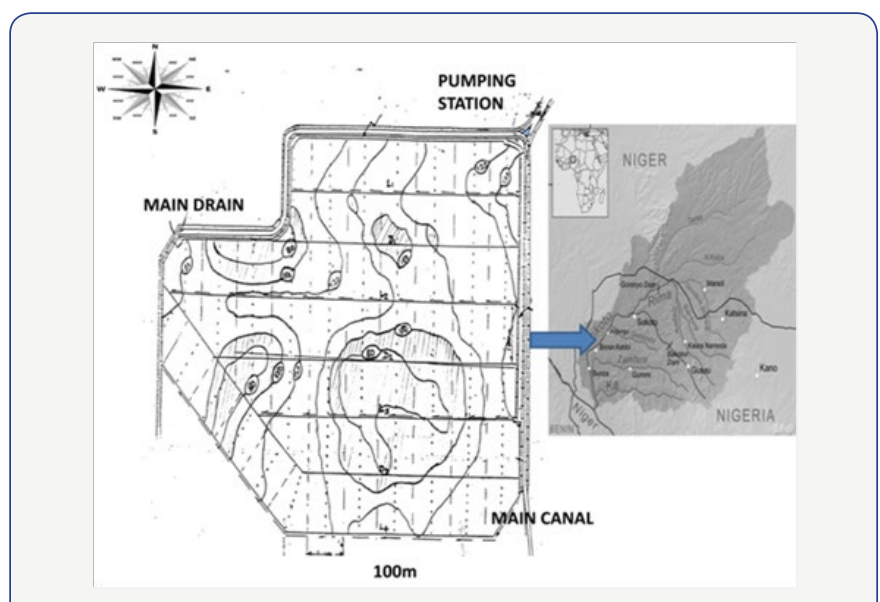

Figure 1: Location of the study area.

The ZPPIS system: The ZPPIS is a 100 ha irrigation scheme located within the fadama area of the Sokoto-Rima river system. It is surrounded by a $2.62 \mathrm{~km}$ flood protective dyke (Figure 1) and has a $545 \mathrm{~m}$ long main canal with four lateral take-offs. These lateral canals are unlined and convey water to the fields where farmers use siphon tubes to apply to basin or border plots Wakuti Consulting Engineers [10].

Presently, however the main canal is silted up and weed infested half-way along its length. This has resulted in problems of water-logging in areas close to the pumping station and inadequate water supply in other sections of the scheme. This means that only farmers who have plots within the vicinity of the pumping station can receive water adequately. The majority of the farmers have had to resort to using self-sunk tube-wells and wash bores to irrigate their fields.

The major crops grown in the ZPPIS are vegetables such as water melon (Citrullus lanatus), green maize (Zea mays) and onions (Allium cepa) in the dry season and rice (Oryza sativa) in the wet season.

The fadama system (FS): The fadama site chosen for this study lies adjacently to the east of the ZPPIS. A few decades ago farming in this area depended on the annual flooding of the Sokoto-Rima system for rice cultivation in the wet season. Dry season farming had to rely on residual moisture (when available) except in areas close to the river where traditional water lifting technologies were used. In the 1990's with the inception of the World Bank funded National Fadama Development Programme this area got a major boost. The farmers were given loans and provided with tube-wells and wash-bores and other incentives.

With this, the farmers are now able to carry out all year round cultivation. In fact, presently due to the deterioration in infrastructure there is very little difference between the cultivation 
system in this area and in some areas of the ZPPIS. The crops grown are similar to those grown in the ZPPIS.

\section{Soil sampling}

Irregularly spaced grids were using in soil sampling at both sites. A Global Positioning Satellite receiver in combination a Google Earth image was used to determine exact locations for sampling. Sampling was done at 18 locations in each site. The samples were taken at depths of $0-15 \mathrm{~cm}$ and $15-30 \mathrm{~cm}$, respectively. Saturated hydraulic conductivity (SHC) measurements were made in-situ using the Inverse Auger Method Oosterbaan \& Nijland [29]. Core samples were also taken at each location for laboratory bulk determination which was estimated using the core method Grossman \& Reinsch [30].

The soil samples were ground and passed through a $2 \mathrm{~mm}$ sieve before further analysis. The hydrometer method was used for particle size analysis Gee \& Or [31] while percentage water stable aggregates (WSA) were determined using the wet sieving method Nimmo \& Perkins [32].

Electrical conductivity was determined in the saturated paste extract in a 1:2 soil to water ratio Rhoades, [33], and soil $\mathrm{pH}$ in a 1:2 soil solution using a pH-meter Thomas [34]. Cation exchange capacity (CEC) was determined by ammonium acetate extraction buffered at $\mathrm{pH}$ 7. Exchangeable cations were extracted with $1 \mathrm{M}$ NH4OAc solution and the exchangeable cations in the extract were determined by using Atomic Absorption Spectrometry $\left(\mathrm{Ca}^{2+}\right.$ and $\left.\mathrm{Mg}^{2+}\right)$ and Flame Photometry $\left(\mathrm{Na}^{+}\right.$and $\left.\mathrm{K}^{+}\right)$, respectively Thomas [34]. Available P, Organic $C$ and Total nitrogen (TN) were determined using the Bray P-1 Extraction (Olsen and Sommers. 1982), WalkleyBlack Wet Combustion and Microkjeldahl Bremner \& Mulvaney [35] methods, respectively. Exchangeable sodium percentage (ESP) was calculated by dividing exchangeable Na by the CEC.

\section{Selecting soil quality indicators}

Soil quality indicators in this study were selected due to:
A. Their ease of analysis;
B. Accessibility to the local farmers;
C. Their sensitivity to variations in the agro-ecological system. The indicators selected include; hydraulic conductivity, bulk density, particle size, aggregate stability, soil $\mathrm{pH}$, electrical conductivity (Ec), exchangeable cations, cation exchange capacity (CEC), available $\mathrm{P}$, organic $\mathrm{C}$, Total $\mathrm{N}$, exchangeable $\mathrm{Na}$ percentage (ESP) and exchangeable $\mathrm{Ca}: \mathrm{Mg}$ ratio.

\section{The soil quality index}

Essentially two different SQI's were developed for this study. One is rice-based (RSQI), while the other is vegetable-based (VSQI). This is because rice has different requirements from the other crops grown, particularly with respect to the soil physical properties.

Because of different indicator units, standard scoring functions (SSF) ["more is better", "less is better", and "optimum"] was used to transform the results obtained from soil analysis into dimension- less scores ranging from 0 to 1 (with one exception). The use of SSF's in soil quality indexing has been described in detail in Hussain et al. [18], Glover et al. [19], Andrews et al. [20]; Masto et al. [23], Karlen \& Scott [36], among others.

Table 1a: Critical limits and scores for crop specific indicators.

\begin{tabular}{|c|c|c|c|c|}
\hline Parameter & $\begin{array}{l}\text { Levels } \\
\text { (Rice) }\end{array}$ & Score & $\begin{array}{c}\text { Levels } \\
\text { (Vegetables ) }\end{array}$ & Score \\
\hline \multirow{5}{*}{ Sand (\%) } & $>50$ & 0 & $<10$ & 0 \\
\hline & $20-50$ & 0.5 & 25 -0ct & 0.5 \\
\hline & \multirow{3}{*}{$<20$} & \multirow{3}{*}{1} & $25-35$ & 1 \\
\hline & & & $35-65$ & 0.5 \\
\hline & & & $>65$ & 0 \\
\hline \multirow{5}{*}{ Clay (\%) } & $<20$ & 0 & $<10$ & 0 \\
\hline & $20-40$ & 0.5 & 15-Oct & 0.5 \\
\hline & \multirow{3}{*}{$>40$} & \multirow{3}{*}{1} & $15-30$ & 1 \\
\hline & & & $30-40$ & 0.5 \\
\hline & & & $>40$ & 0 \\
\hline \multirow{3}{*}{$\begin{array}{l}\text { Bulk density (g } \\
\mathrm{kg}^{-1} \text { ) }\end{array}$} & $<1.20$ & 0 & $>1.50$ & 0 \\
\hline & $1.20-1.50$ & 0.5 & $1.20-1.50$ & 0.5 \\
\hline & $>1.50$ & 1 & $<1.20$ & 1 \\
\hline \multirow{5}{*}{$\begin{array}{c}\text { Hydraulic } \\
\text { conductivity (cm } \\
\text { hr-1) }^{-1}\end{array}$} & $>6.0$ & 0 & $<2.0$ & 0 \\
\hline & $2.0-6.0$ & 0.5 & $2.0-6.0$ & 0.5 \\
\hline & \multirow{3}{*}{$<2.0$} & \multirow{3}{*}{1} & $6.0-8.0$ & 1 \\
\hline & & & $8.0-10.0$ & 0.5 \\
\hline & & & $>10.0$ & 0 \\
\hline \multirow{5}{*}{$\begin{array}{c}\text { Exchangeable } \\
\text { sodium percentage } \\
\text { (\%) }\end{array}$} & $<10$ & 0 & $>20$ & 0 \\
\hline & 20-Oct & 0.5 & $20-0 \mathrm{ct}$ & 0.5 \\
\hline & $20-30$ & 1 & \multirow{3}{*}{$<10$} & \multirow{3}{*}{1} \\
\hline & $30-50$ & 0.5 & & \\
\hline & $>50$ & 0 & & \\
\hline \multirow{3}{*}{$\begin{array}{c}\text { Electrical } \\
\text { conductivity (mS } \\
\left.\mathrm{kg}^{-1}\right)\end{array}$} & $>5.0$ & 0 & $>4.0$ & 0 \\
\hline & $3.0-5.0$ & 0.5 & $2.0-4.0$ & 0.5 \\
\hline & $<3.0$ & 1 & $<2.0$ & 1 \\
\hline
\end{tabular}

The soil quality indicators that are scored differently with respect to the two indexes are presented in (Table 1a). Clay percentages was scored with the more is better curve (used for SQ indicators that are associated with good soil quality at high levels) for the RSQI, but with the VSQI, they were scored with an optimum curve. This is because rice generally thrives in fine textured soils. For vegetables these two indicators have an increasingly positive effect on soil quality up to a certain point (optimum level) beyond which their effect is detrimental. For the same reason, SHC was scored with a more is better curve for the RSQI and the optimum curve for the VSQI.

High soil bulk density with its consequent low soil permeability would be conducive for rice growth but detrimental to the other crops. Therefore, bulk density was scored with the more is better 
curve for The RSQI and less is better (used for SQ indicators that indicate good soil quality at low levels) for the VSQI. Rice has a moderately high tolerance to exchangeable sodium arising from its need for, a layer of water on the field throughout the growing season. The low permeability of sodic soils is also an added advantage to rice because losses of water due to deep percolation are restricted Abrol et al. [37]. Taking this into consideration, ESP was scored with an optimum curve for the RSQI but less is better for the VSQI.

Electrical conductivity on the other hand was scored for both indices with a less is better curve. The exception being that higher values were given for the RSQI as can be shown in (Table 1a). This is because rice can tolerate higher levels of salinity because the maintenance of standing water almost throughout the growing season brings about a significant reduction in the root zone salinity by leaching and dilution of the salts. Thus the crop is at no stage subjected to the salinity stress that might be indicated by the initial soil analysis Abrol et al. [37].

Table 1b: Critical limits and scores for non-crop specific indicators.

\begin{tabular}{|c|c|c|}
\hline Parameter & Levels & Score \\
\hline \multirow{3}{*}{ Aggregate stability (\%) } & $<30$ & 0 \\
\hline & $30-70$ & 0.5 \\
\hline & $>70$ & 1 \\
\hline \multirow{5}{*}{ Soil pH } & $<4.5$ & 0 \\
\hline & $4.5-5.5$ & 0.5 \\
\hline & $5.5-7.0$ & 1 \\
\hline & $7.0-8.5$ & 0.5 \\
\hline & $>8.5$ & 0 \\
\hline \multirow{3}{*}{ Organic C $\left(\mathrm{g} \mathrm{kg}^{-1}\right)$} & $<10.0$ & 0 \\
\hline & $10.0-15.0$ & 0.5 \\
\hline & $>15.0$ & 1 \\
\hline \multirow{3}{*}{ Total N ( $\left.\mathrm{g} \mathrm{kg}^{-1}\right)$} & $<1.5$ & 0 \\
\hline & $1.5-2.0$ & 0.5 \\
\hline & $>2.0$ & 1 \\
\hline Available P (mg kg-1) & $<10.0$ & 0 \\
\hline
\end{tabular}

\begin{tabular}{|c|c|c|}
\hline & $10.0-20.0$ & 0.5 \\
\hline & $>20.0$ & 1 \\
\hline \multirow{3}{*}{$\mathrm{CEC}\left(\mathrm{cmol} \mathrm{kg}^{-1}\right)$} & $<6.0$ & 0 \\
\hline & $6.0-12.0$ & 0.5 \\
\hline & $>12.0$ & 1 \\
\hline \multirow{3}{*}{ Exch. $\mathrm{K}\left(\mathrm{cmol} \mathrm{kg}^{-1}\right)$} & $<0.15$ & 0 \\
\hline & $0.15-0.30$ & 0.5 \\
\hline & $>0.30$ & 1 \\
\hline \multirow{3}{*}{ Exch. Ca $\left(\mathrm{cmol} \mathrm{kg}^{-1}\right)$} & $<2.0$ & 0 \\
\hline & $2.0-5.0$ & 0.5 \\
\hline & $>5.0$ & 1 \\
\hline \multirow{3}{*}{ Exch. Mg ( $\left.\mathrm{cmol} \mathrm{kg}^{-1}\right)$} & $<0.3$ & 0 \\
\hline & $0.3-1.0$ & 0.5 \\
\hline & $>1.0$ & 1 \\
\hline \multirow{2}{*}{ Exch.Ca: Mg } & $<1$ & 0 \\
\hline & $>1$ & 1 \\
\hline
\end{tabular}

(Table 1b) presents the soil quality indicators that were scored with the scoring curves for both SQI's. The more is better curve is used for percentage water stable aggregates WSA, CEC, exchangeable cations, organic carbon, available $\mathrm{P}$ and total nitrogen, while Soil pH was scored with the optimum used. The exception to all this was the Ca: Mg ratio, which was scored 0 or 1 depending on whether the value was below or above 1 . This is because a Ca: $\mathrm{Mg}<1$ has similar effects as high ESP and may result in nutrient imbalances in the soils.

The SQ indicators were then scored using critical values based on published values. The critical values for the soil physical indicators were adapted from Landon [38] while those for the chemical indicators were taken from Enwezor et al. [39] and Esu [40].

Soil quality was evaluated with respect to four soil attributes that are of importance to irrigated agriculture. These include; nutrient relations, water relations, soil physical stability/support and salt constraints. These attributes being generally of equal importance were given equal weights of 0.25 each (Table 2 ).

Table 2: Framework and scorecard for the Soil Quality Index.

\begin{tabular}{|c|c|c|c|c|c|}
\hline \multicolumn{6}{|c|}{ Indicators } \\
\hline Function & Weight & Level I & Weight & Level II & Weight \\
\hline \multirow{7}{*}{ Nutrient relations } & \multirow{7}{*}{0.25} & \multirow{7}{*}{ Nutrient availability } & \multirow{7}{*}{0.8} & Organic C & 0.2 \\
\hline & & & & Exch. K & 0.15 \\
\hline & & & & Total N & 0.15 \\
\hline & & & & Available P & 0.15 \\
\hline & & & & CEC & 0.1 \\
\hline & & & & Exch. Ca & 0.1 \\
\hline & & & & Exch. Mg & 0.1 \\
\hline
\end{tabular}


Agricultural Research \& Technology: Open Access Journal

\begin{tabular}{|c|c|c|c|c|c|}
\hline & & & & Soil pH & 0.05 \\
\hline & & \multirow{2}{*}{ Nutrient constraints } & \multirow{2}{*}{0.2} & ESP & 0.5 \\
\hline & & & & Ca:Mg & 0.5 \\
\hline \multirow{13}{*}{ Water relations } & \multirow{13}{*}{0.25} & \multirow{5}{*}{ Water availability } & \multirow{5}{*}{0.6} & $\mathrm{HC}$ & 0.2 \\
\hline & & & & $\mathrm{BD}$ & 0.2 \\
\hline & & & & $\mathrm{Cl}$ & 0.2 \\
\hline & & & & ESP & 0.2 \\
\hline & & & & Ca:Mg & 0.2 \\
\hline & & \multirow{5}{*}{$\begin{array}{c}\text { Physical stability and } \\
\text { support }\end{array}$} & \multirow{5}{*}{0.2} & Organic C & 0.2 \\
\hline & & & & $\mathrm{BD}$ & 0.2 \\
\hline & & & & Clay & 0.2 \\
\hline & & & & AS & 0.2 \\
\hline & & & & Ca:Mg & 0.2 \\
\hline & & \multirow{3}{*}{$\begin{array}{l}\text { Salinity/ sodicity } \\
\text { constraints }\end{array}$} & \multirow{3}{*}{0.2} & ESP & 0.4 \\
\hline & & & & Ec & 0.4 \\
\hline & & & & Ca:Mg & 0.2 \\
\hline \multirow{7}{*}{$\begin{array}{l}\text { Physical stability and } \\
\text { support }\end{array}$} & \multirow{7}{*}{0.25} & Organic C & 0.2 & & \\
\hline & & AS & 0.2 & & \\
\hline & & BD & 0.1 & & \\
\hline & & Clay & 0.1 & & \\
\hline & & Sand & 0.1 & & \\
\hline & & ESP & 0.15 & & \\
\hline & & Ca:Mg & 0.15 & & \\
\hline \multirow{3}{*}{ Salt Constraints } & \multirow{3}{*}{0.25} & ESP & 0.4 & & \\
\hline & & Ec & 0.4 & & \\
\hline & & $\mathrm{pH}$ & 0.2 & & \\
\hline
\end{tabular}

Abbreviation: ESP: Exchangeable Sodium Percentage; HC: Hydraulic Conductivity; BD: Bulk Density; AS: Aggregate Stability; EC: Electrical Conductivity.

The nutrientrelations attribute was divided intolevel Iindicators of nutrient availability and nutrient constraint receiving 0.80 and 0.20 , respectively. With respect to nutrient availability, organic $\mathrm{C}$ which according to Bastida et al. (2008) is the star SQ indicator in agricultural soils was given the highest score (0.20). This is because organic $\mathrm{C}$ is involved in and related to many soil biological, chemical and physical processes. For nutrient constraints, ESP and Ca: Mg ratio were included for the following reasons:

A. Excessive levels of ions such as $\mathrm{Na}^{+}$and $\mathrm{Cl}^{-}$in soils may cause specific ion effects in plants leading to toxicity or deficiency of certain nutrients (Qadir and Schubert, 2002);

B. Sodic soils have poor physical properties which result in poor seedling emergence and root growth which have indirect effects on plant nutrition by restricting water and nutrient uptake and gaseous exchange Curtin \& Naidu [41].

C. Excess levels of $\mathrm{Mg}^{+}(\mathrm{Ca}: \mathrm{Mg}<1)$ also have similar effects on soils as high $\mathrm{Na}^{+}$and in addition may also lead to $\mathrm{Ca}^{+}$deficiency in plants.

Water availability, physical stability/support and salt constraints were selected level I indicators for the water relations attribute. Water availability was given greater importance (score:
0.60) than the other level I indicators (Table 2). Soil saturated hydraulic conductivity (SHC), bulk density, clay content, ESP and Ca: Mg ratio all directly and indirectly influence the amount of water that is available for plant uptake. This is actually the main purpose of irrigation. For the physical stability/support, organic C, bulk density, clay content, WSA and Ca: Mg were selected as level II indicators. These indicators increase the soils resistance to physical degradation which indirectly influences water availability.

The salinity/sodicity status of soils was selected as a level I indicator as this may also be an indirect indicator of water availability for plant uptake (Table 2). The dispersive effects of high $\mathrm{Na}^{+}$and $\mathrm{Mg}^{+}$and the counteractive flocculative effects of $\mathrm{Ca}^{+}$ on soils all influence water availability negatively and positively, respectively. High electrical conductivity also has a positive effect on soil permeability. In this case the scores for Ec in (Table 1a) were reversed to reflect this.

The third soil attribute used for the SQI in this study is physical stability/support. The SQ indicators selected for this attribute are shown in (Table 2). Irrigated soils are especially prone to physical degradation and all the indicators selected in this soil attribute all help to boost the soils resistance to physical degradation. 
The fourth attribute is the salinity/sodicity constriants. This is a major problem associated with irrigated soils. The indicators selected are the parameters used to define saline, saline-sodic and sodic soils. In saline soils, plant growth is adversely chiefly through the effect of excess salts on the osmotic pressure of soil solution resulting in reduced availability of water and through toxicity of specific ions, such as $\mathrm{Na}, \mathrm{Cl}, \mathrm{B}$, etc. Sodic soils also negatively affect plant growth chiefly through the dispersive effect of excess exchangeable sodium resulting in poor physical properties and also through toxicity of specific ions, such as $\mathrm{Na}, \mathrm{CO} 3$, Mo, etc. High soil $\mathrm{pH}$, usually associated with sodic soils create nutritional imbalances in soils including a deficiency of calcium Abrol et al. [37].

A soil quality score card based on (Table 2) was developed using Microsoft Excel software. The determination of the soil attribute scores was made by summing the products of the weights of their associated indicators and the normalized soil indicator scores. The four soil attributes were then summed up to give the total soil quality score.

\section{Results}

\section{Soil physio-chemical properties}

There was a wide variability in soil textural properties within each of the irrigation systems. However, when comparing the two systems the sand and clay contents were not significantly different (Table 3a). The FS soils had significantly higher $(\mathrm{P}<0.05)$ bulk density than the ZPPIS soils. There was also a wider variation in soil bulk density within the FS than within the ZPPIS (Table 3a). The soils of the ZPPIS had significantly lower $(\mathrm{P}<0.001)$ SHC than the soils of the FS (Table 3a). There were however, no statistically significant differences between the soils of both irrigation systems with respect to soil aggregate stability.

Table 3a: Descriptive statistics and t-test results for soil physical properties and salinity/sodicity indicators.

\begin{tabular}{|c|c|c|c|c|c|c|c|c|c|}
\hline \multicolumn{5}{|c|}{ ZPPIS } & \multicolumn{5}{|c|}{ Fadama } \\
\hline Parameter & Min & Max & Mean \pm SE & CV (\%) & Min & Max & Mean \pm SE & CV (\%) & T-test \\
\hline Sand (\%) & 32 & 92 & $69.1 \pm 5.1$ & 31.5 & 16 & 78 & $63.7 \pm 4.0$ & 26.4 & ns \\
\hline Silt (\%) & 1 & 28 & $7.0 \pm 1.9$ & 112.7 & 7 & 24 & $12.4 \pm 1.2$ & 40.9 & * \\
\hline Clay (\%) & 6.2 & 64 & $23.9 \pm 4.7$ & 83 & 12 & 44 & $21.4 \pm 2.0$ & 39.3 & ns \\
\hline Bulk density ( $\mathrm{g} \mathrm{kg}^{-1}$ ) & 1.17 & 1.39 & $1.26 \pm 0.02$ & 5.6 & 1.17 & 1.5 & $1.33 \pm 0.03$ & 75.2 & $*$ \\
\hline $\begin{array}{l}\text { Hydraulic conductivity } \\
\left(\mathrm{cm} \mathrm{hr}^{-1}\right)\end{array}$ & 0.02 & 1 & $0.16 \pm 0.06$ & 149 & 1.1 & 9.9 & $4.8 \pm 0.6$ & 50.2 & $* * *$ \\
\hline Aggregate stability (\%) & 21 & 73 & $43.3 \pm 3.6$ & 35.7 & 23 & 54 & $36.4 \pm 2.3$ & 26.9 & ns \\
\hline ESP (\%) & 21 & 40 & $32.5 \pm 2.0$ & 20.5 & 3.4 & 12.3 & $8.5 \pm 0.5$ & 29.2 & $* * *$ \\
\hline $\begin{array}{l}\text { Electrical conductivity } \\
\qquad\left(\mathrm{mS} \mathrm{cm}^{-1}\right)\end{array}$ & 0.12 & 1.25 & $0.42 \pm 0.08$ & 75.7 & 0.01 & 0.95 & $0.29 \pm 0.06$ & 87.7 & ns \\
\hline
\end{tabular}

Abbreviation: SE: Standard Error; CV: Coefficient of Variation; ns: Not Significant; ${ }^{*}=$ significant at $5 \%,{ }^{* * *}=$ significant at $0.1 \%$

The ZPPIS soils had significantly higher $(\mathrm{P}<0.001)$ levels of ESP than the FS soils (Table 3a). The minimum value of ESP obtained in The ZPPIS exceeds the threshold value of $15 \%$ that differentiates sodic from non-sodic soils (US Salinity Laboratory Staff, 1954). None of the soil samples obtained from the FS had ESP levels exceeding this value. In an earlier study conducted in 1999 (16 years after impoundment), Graham (2000) reported ESP values ranging from 7.8 to $15.9 \%$ (mean, $11.7 \%$ ) in the soils of the ZPPIS. This indicates a greater than 100\% increase in ESP in the soils of the ZPPIS over a 12 year period (this study being conducted in 2010/11).

Table 3b: Descriptive statistics and t-test results for soil chemical properties.
With respect to soil salinity, the Ec values obtained though showing very wide variability within each system were not significantly different between the two systems (Table 3a). The ZPPIS had significantly higher $(\mathrm{P}<0.001)$ soil $\mathrm{pH}$ than the FS soils (Table $3 \mathrm{~b}$ ). Soil $\mathrm{pH}$ in the ZPPIS ranged from slightly alkaline to strongly alkaline, while in the FS soil pH ranged very strongly acid to slightly alkaline (Soil Survey Division Staff, 1993). Most fadama soils tend to be inherently slightly acidic Esu [42]: Owonubi et al. [43]; Kparmwang \& Malgwi [44]; Singh [45,46]; Graham [47,48]; Esu \& Akpan-Idiok [49].

\begin{tabular}{|c|c|c|c|c|c|c|c|c|c|}
\hline \multicolumn{5}{|c|}{ ZPPIS } & \multicolumn{5}{|c|}{ Fadama } \\
\hline Parameter & Min & Max & Mean \pm SE & CV (\%) & Min & Max & Mean $\pm S E$ & CV (\%) & T-test \\
\hline Soil pH & 7.4 & 8.9 & $8.2 \pm 0.09$ & 4.8 & 4.9 & 7.8 & $5.8 \pm 0.17$ & 12.6 & $* * *$ \\
\hline Organic C & \multirow{2}{*}{1} & \multirow{2}{*}{28} & \multirow{2}{*}{$12.0 \pm 2.1$} & \multirow{2}{*}{77.2} & \multirow{2}{*}{2.5} & \multirow{2}{*}{24} & \multirow{2}{*}{$10.2 \pm 0.15$} & \multirow{2}{*}{63.7} & \multirow{2}{*}{ ns } \\
\hline$\left(\mathrm{g} \mathrm{kg}^{-1}\right)$ & & & & & & & & & \\
\hline Total N $\left(\mathrm{g} \mathrm{kg}^{-1}\right)$ & 0.3 & 2.2 & $1.1 \pm 0.14$ & 55.6 & 0.2 & 2.8 & $1.0 \pm 0.16$ & 66.6 & ns \\
\hline Available P & 1.8 & 5.2 & $3.1 \pm 0.22$ & 29.7 & 0.14 & 5.63 & $2.1 \pm 0.38$ & 76 & * \\
\hline
\end{tabular}




\section{Agricultural Research \& Technology: Open Access Journal}

\begin{tabular}{|c|c|c|c|c|c|c|c|c|c|}
\hline$\left(\mathrm{mg} \mathrm{kg}^{-1}\right)$ & & & & & & & & & \\
\hline CEC & \multirow{2}{*}{9.6} & \multirow{2}{*}{22.4} & \multirow{2}{*}{$14.5 \pm 0.84$} & \multirow{2}{*}{24.4} & \multirow{2}{*}{5} & \multirow{2}{*}{22.5} & \multirow{2}{*}{$14.7 \pm 1.21$} & \multirow{2}{*}{35.2} & \multirow{2}{*}{ ns } \\
\hline$\left(\mathrm{cmol} \mathrm{kg}^{-1}\right)$ & & & & & & & & & \\
\hline Exch. K & \multirow{2}{*}{1.5} & \multirow{2}{*}{7.8} & \multirow{2}{*}{$3.6 \pm 0.38$} & \multirow{2}{*}{44.4} & \multirow{2}{*}{1.4} & \multirow{2}{*}{6.9} & \multirow{2}{*}{$2.8 \pm 0.36$} & \multirow{2}{*}{54.1} & \multirow{2}{*}{$*$} \\
\hline$\left(\mathrm{cmol} \mathrm{kg}^{-1}\right)$ & & & & & & & & & \\
\hline Exch. Ca & \multirow{2}{*}{0.5} & \multirow{2}{*}{1.8} & \multirow{2}{*}{$0.9 \pm 0.08$} & \multirow{2}{*}{38.9} & \multirow{2}{*}{0.3} & \multirow{2}{*}{3.2} & \multirow{2}{*}{$1.5 \pm 0.20$} & \multirow{2}{*}{57.9} & \multirow{2}{*}{ * } \\
\hline$\left(\mathrm{cmol} \mathrm{kg}^{-1}\right)$ & & & & & & & & & \\
\hline Exch. Mg & \multirow{2}{*}{0.7} & \multirow{2}{*}{3.3} & \multirow{2}{*}{$1.7 \pm 0.15$} & \multirow{2}{*}{38.4} & \multirow{2}{*}{0.9} & \multirow{2}{*}{6.3} & \multirow{2}{*}{$1.7 \pm 0.30$} & \multirow{2}{*}{72} & \multirow{2}{*}{ ns } \\
\hline$\left(\mathrm{cmol} \mathrm{kg}^{-1}\right)$ & & & & & & & & & \\
\hline Exch. Na & \multirow{2}{*}{3.1} & \multirow{2}{*}{7.1} & & & & & & & \\
\hline$\left(\mathrm{cmol} \mathrm{kg}^{-1}\right)$ & & & $4.0 \pm 1.03$ & 19.5 & 0.2 & 4.4 & $1.3 \pm 0.13$ & 40 & \\
\hline Exch. Ca:Mg & 0.23 & 1 & $0.6 \pm 0.06$ & 5 & 0.08 & 3.6 & $1.2 \pm 0.23$ & 8 & $*$ \\
\hline
\end{tabular}

Abbreviation: SE: Standard Error, CV: Coefficient of Variation, ns $=$ not significant, ${ }^{*}=$ significant at $5 \%,{ }^{* * *}=$ significant at $0.1 \%$

With respect to organic- $C$, the results show no significant difference between the soils of the two irrigation systems. However, there was a very wide range of organic-C contents of the soils within each irrigation system. This ranged from very low to high values. This is a typical characteristic of fadama soils (Table $3 \mathrm{~b}$ ). There was also no significant difference between the two irrigation systems with respect to soil total $\mathrm{N}$. The total $\mathrm{N}$ contents of the soils within each site also ranged from very low to very high (Table 1b). The available P content of the soils of both irrigation systems fell below the critical limits in both systems. The soils of the ZPPIS however, had significantly higher $(\mathrm{P}<0.05)$ available $\mathrm{P}$ than the FS soils, perhaps due to the fact that soil $\mathrm{P}$ tends to be more readily available to plants in sodic soils than in similar non-sodic soils Chhabra [50].

There was no significant difference between CEC values obtained for both irrigation systems, perhaps due to the similarity in the clay and organic matter contents of both sites. Both sites had significant differences with respect to $\mathrm{K}^{+}$and $\mathrm{Ca}^{+}$and $\mathrm{Na}^{+}$, while there was no significant difference in regards to $\mathrm{Mg}^{+}$content of the soils (Table $3 \mathrm{~b}$ ), with the ZPPIS soils having significantly higher levels of $\mathrm{K}^{+}(\mathrm{P}<0.05)$ and $\mathrm{Na}^{+}(\mathrm{P}<0.001)$ and significantly lower $(\mathrm{P}<0.05)$ levels of $\mathrm{Ca}^{+}$than the FS soils. The FS had a significantly higher $(\mathrm{P}<0.05) \mathrm{Ca}$ : Mg ratio than the ZPPIS soils.

\section{The Rice based soil quality index}

Table 4: Descriptive statistics and t-test results for soil attributes and total RSQI scores.

\begin{tabular}{|c|c|c|c|c|c|c|c|c|c|}
\hline \multicolumn{9}{|c|}{ ZPPIS } & \multicolumn{4}{c|}{ Fadama } \\
\hline Parameter & Min & Max & Mean \pm SE & CV (\%) & Min & Max & Mean \pm SE & CV (\%) & $\begin{array}{c}\text { T-test } \\
\text { Significance }\end{array}$ \\
\hline Nutrient Relations & 0.063 & 0.18 & $0.117 \pm 0.008$ & 31 & 0.07 & 0.135 & $0.107 \pm 0.003$ & 13.8 & $\mathrm{~ns}$ \\
\hline Water relations & 0.095 & 0.225 & $0.160 \pm 0.008$ & 22.1 & 0.04 & 0.2 & $0.099 \pm 0.009$ & 39.9 & $* * *$ \\
\hline $\begin{array}{c}\text { Physical Stability/ } \\
\text { Support }\end{array}$ & 0.031 & 0.163 & $0.095 \pm 0.009$ & 42.8 & 0.038 & 0.144 & $0.082 \pm 0.005$ & 28.2 & $\mathrm{~ns}$ \\
\hline Salt Relations & 0.15 & 0.25 & $0.182 \pm 0.006$ & 13.2 & 0.125 & 0.2 & $0.172 \pm 0.006$ & 15.7 & $\mathrm{~ns}$ \\
\hline Total Soil Quality Index & 0.439 & 0.738 & $0.554 \pm 0.022$ & 16.5 & 0.36 & 0.584 & $0.459 \pm 0.016$ & 15.2 & $*$ \\
\hline
\end{tabular}

Abbreviation: SE: Standard Error; CV: Coefficient of Variation; NS: Not Significant; ${ }^{*}=$ significant at $5 \%,{ }^{* * *}=$ significant at $0.1 \%$.

Results pertaining to the RSQI are presented in Table 4 In evaluating the quality of soils; a soil quality rating (SQR) was developed for this study. The individual soil functions were rated as: Poor soil quality $(<0.100)$; good soil quality $(0.100-0.200)$ and excellent soil quality $(>0.200)$. For the total SQI, the rating was: Poor soil quality $(<0.400)$; good soil quality $(0.400-0.800)$ and excellent soil quality $(>0.800)$. With respect to the nutrient relations function, there was no statistically significant difference between both irrigation systems. In both irrigation systems, the SQR ranged from poor to good soil quality. On the average, the two irrigation systems had good soil quality. When considering the water relations function, there was a significant difference between both systems.
The ZPPIS soils had significantly higher $(\mathrm{P}<0.001)$ scores than the FS soils. Soil quality with respect to water relations ranged from poor to excellent in the ZPPIS and poor to good soil quality in the FS. However, with respect to the mean SQR, the soils of the ZPPIS, rated good while the soils of the FS rated poor in SQ.

The mean score for the physical stability/support function obtained for the FS soils was higher than that obtained for the ZPPIS soils. The mean scores however, rated poor in SQ and the difference between the two systems was not significant. In respect to the salt relations function, all the samples obtained from both sites rated good in SQ with some samples in the ZPPIS having a perfect score of 0.25 . 
The ZPPIS soils had significantly $(\mathrm{P}<0.05)$ better overall SQ (TSQI) than the soils of the FS. All the samples studied in the ZPPIS rated good in SQ those of the FS rated poor in some sections and good in others. However, when the mean values are considered, the soils of both sites had good SQ. As can be seen from above, the significant difference in TSQI between both irrigation systems is for the most part due to the significant difference with respect to the water relations function.

Table 5: Descriptive statistics and t-test results for soil attributes and total VSQI scores.

\begin{tabular}{|c|c|c|c|c|c|c|c|c|c|}
\hline \multicolumn{9}{|c|}{ ZPPIS } & \multicolumn{4}{c|}{ Fadama } \\
\hline Parameter & Min & Max & Mean \pm SE & CV (\%) & Min & Max & Mean \pm SE & CV (\%) & $\begin{array}{c}\text { T-test } \\
\text { Significance }\end{array}$ \\
\hline Nutrient Relations & 0.055 & 0.145 & $0.098 \pm 0.008$ & 32.4 & 0.093 & 0.18 & $0.126 \pm 0.005$ & 16 & $* *$ \\
\hline Water relations & 0.045 & 0.125 & $0.074 \pm 0.005$ & 31.2 & 0.11 & 0.225 & $0.162 \pm 0.007$ & 18.6 & $* * *$ \\
\hline $\begin{array}{c}\text { Physical Stability/ } \\
\text { Support }\end{array}$ & 0.013 & 0.138 & $0.067 \pm 0.009$ & 59.2 & 0.075 & 0.175 & $0.118 \pm 0.008$ & 27.1 & $* * *$ \\
\hline $\begin{array}{c}\text { Salt Relations } \\
\text { Total Soil Quality Index }\end{array}$ & 0.1 & 0.125 & $0.121 \pm 0.002$ & 7.9 & 0.175 & 0.25 & $0.228 \pm 0.006$ & 11.6 & $* * *$ \\
\hline
\end{tabular}

Table 5 presents the results relating to the VSQI. With respect to nutrient relations, The SQR in both systems ranged from poor SQ to good SQ although, the SQ scores obtained in the FS was significantly higher $(\mathrm{P}<0.01)$ than that obtained for the ZPPIS. The results for the water relations function for the VSQI were essentially in reverse to that obtained for the RSQI. The FS soils had significantly higher $(\mathrm{P}<0.001)$ scores than the ZPPIS soils. The ratings for the water relations function ranged from poor to good SQ in the ZPPIS but in the FS ranged from good to excellent SQ. There was a significant difference in the scores obtained for the physical stability/support function between the two systems. In contrast to the RSQI, the soils of the FS outperformed the soils of the ZPPIS with a significantly higher $(\mathrm{P}<0.001)$ TSQI.

\section{Discussion}

\section{Soil physio-chemical properties}

There are usually wide variations in soil texture among and within fadamas. This is related to the size of the sediments deposited, as affected by the speed of water during deposition along the micro-topography. This difference may be due to dissimilar management practices. Being a formal irrigation scheme, the farmers in the ZPPIS tend to form informal cooperatives and carryout similar management practices such land preparation with similar machinery. This may explain the very low variability in soil bulk density within the ZPPIS. In contrast, the FS farmers usually work individually and carryout a diverse range of management practices, explaining the very wide variability in soil bulk density in the FS.

High values of SHC (> $12 \mathrm{~cm} \mathrm{hr}^{-1}$ ) are associated with well structured soil and contiguous pores and result in high infiltration rates and rapid drainage, while low $\mathrm{HC}$ values $\left(<1.0 \mathrm{~cm} \mathrm{hr}^{-1}\right)$ are likely to produce runoff and in irrigation projects without adequate drainage, ponding of water on the surface Pearson et al. [51]. Soil SHC usually varies with soil type and management but may also be a reflection of the ESP status (Table 3a) of the different soils. This could be attributed to the fact that the soils of both sites had significantly similar clay (Table 3a) and organic-C contents. Aggregate stability is a complex function of soil texture, clay mineralogy, organic matter content and the concentration of exchangeable bases Ozgoz et al. [52].

The very high ESP in the ZPPIS soils can be attributed to the complete lack of drainage in the ZPPIS and is probably responsible for the very low SHC of the ZPPIS soils. High ESP leads to a physical deterioration (by soil dispersion) in soil quality particularly with respect to the behaviour of water in soils resulting in very low infiltration of water into the soils. The very low soil salinity (Ec $<2$ $\mathrm{mS} \mathrm{cm}{ }^{-1}$ ) in both the ZPPIS and FS would have very negligible effects on crop plants. However, very low soil salinity can have adverse effects on soil physical properties resulting in poor soil structure and reduced permeability to water Abrol et al. [52].

The slight acidity in the fadama soils may be attributed to dissociation of strongly acid functional groups in the organic matter, which are rather high in the Ap horizons as well as redox products of ferrolysis, which is common in slowly permeable hydric soils Esu \& Akpan-Idiok [49], Brinkman [53]. The alkalinity of the soils of the ZPPIS could be related to the high ESP of the soils. Sodic soils usually have $\mathrm{pH}$ values that may range above 8.5.

The very wide variability in the organic $C$ content of the soils in general may be attributed to the non-uniform periodic addition of organic materials Owonubi et al. [43]. The total $\mathrm{N}$ content of fadama soils usually tends to be quite low. The high values of total $\mathrm{N}$ obtained in this study may be due to $\mathrm{N}$-fertilization, particularly urea. Urea is the main fertilizer of choice for fadama farmers in the SRB (Graham 2009a, b). Phosphorus has been described as the most deficient nutrient in the fadama Ipinmidun [54] and this is mainly due to fixation as $\mathrm{Fe}$ and $\mathrm{Al}$ phosphates in acidic or alkaline environments.

\section{The rice based soil quality index}

The significant difference between the SQ values soils of both systems is primarily due to significantly higher ESP in combination with the very low salinity of the soils located in the ZPPIS (Table 3a). The prime soil response to excessive exchangeable sodium 
when combined with low salinity is degradation in soil structure which results in a deterioration in soil air and water permeability. However, these are usually optimum conditions conducive for rice production. This further underscores the fact that the salinity/ sodicity status of the soils in the ZPPIS would not in any way limit rice production. There was no significant difference in scores however, between the two sites.

\section{The vegetable based soil quality index}

The significant difference between SQ scores obtained for the two irrigation systems can be attributed to nutrient constraints caused by very high ESP and the fact that most of the soils in the ZPPIS had Ca:Mg ratios less than 1. The significant difference between soils of both systems is mainly due to significantly higher ESP in the ZPPIS which results in conditions not suitable for growing most other crops except rice (Table 3a).

The results presented in (Table 5) indicate that the soils of the FS are more resistant to physical degradation than the soils of the ZPPIS. Again this can be attributed to the significantly higher ESP in the soils of the ZPPIS. Sodic soil conditions lead to the destruction of topsoil aggregates during the wetting phase through the degradation processes such as slaking and dispersion. As a consequence of the rearrangement of soil particles during such processes, a densely packed thin soil layer with high shear strength may be developed on the surface upon drying, which is called structural crust or seal McIntyre, [55]; Moore \& Singer [56]; Qadir \& Schubert [57].

Hard setting is another type of soil degradation associated with sodic soils. The major difference between hard setting and crusting soils is that hard setting leads to complete aggregate breakdown and clay movement within the entire Ap horizon, whereas in crusting soils, clay mobility is restricted to the top few millimetres. Soil crusts and hardsetting in soils lead to a reduction in infiltration rate, and a consequent increase in runoff and erosion Qadir \& Schubert [57]. The excess levels of $\mathrm{Mg}^{+}$(Ca: $\mathrm{Mg}<1$ ) occurring in the soils of the ZPPIS is also a contributory factor to the lower scores obtained for the physical stability/support function.

All the sampled soils in the FS had good SQ, while those of the ZPPIS on the average rated poor in SQ. This is not surprising since the FS soils had higher scores with respect to all four soil attributes considered [58-67].

\section{Conclusion}

A soil quality index must be site and crop specific. This study illustrates that twenty seven years of the impoundment in the ZPPIS has led to a rather moderate improvement in SQ when using the rice based SQI. With respect to the RSQI, the major contributing factor to the difference in SQ scores between the two irrigation systems was the water relations attribute. This is paradoxically due to deterioration in soil physical properties consequent of high soil ESP in the ZPPIS. On the contrary, the impoundment has lead to drastic reduction in SQ in the ZPPIS, when considering vegetable production. When using the vegetable based SQI, the FS soils were superior to the ZPPIS soils after 27 years of impoundment. Based on this index, the FS soils outperformed the ZPPIS soils with respect to all soil attributes considered and the total SQ.

It is therefore suggested that the planners of the main Zauro Polder Project weigh the positive and negative long term impacts on crop production within the project area. Obviously, impoundment would lead to a slight benefit in regards to rice production to the detriment of other crops.

\section{References}

1. SFAO (Food and Agriculture Organization of the United Nations) (1969) Soil and Water Resource Survey of the Sokoto Valley. FAO/SF: 67/NIR 3. FAO, Rome, Italy.

2. Graham WBR, Alabi JB, Pishriria IW (2003a) Water and agriculture in the Sokoto Rima Basin. 2. An appraisal of formal irrigation schemes. Proceedings of the $4^{\text {th }}$ International Conference of the Nigerian Institution of Agricultural Engineers, 25: 120-126.

3. Graham WBR, Alabi JB, Pishriria IW (2003b) Water and agriculture in the Sokoto Rima Basin 3. An appraisal of non-formal irrigation. Proceedings of the $4^{\text {th }}$ International Conference of the Nigerian Institution of Agricultural Engineers, 25: 127-134.

4. Kolawole A, Scoones I (1994) Fadama land use and sustainability in northern Nigeria: An overview. In Kolawole A, et al. (Eds.), Strategies for the Sustainable use of Fadama Lands in Northern Nigeria, CSER/ IIED, Nigeria, p. 29-34.

5. Arnborg T (1988) Where Savanna Turns into Desert. Experiences from the Sudan savanna zone in Sokoto State, Nigeria. International Rural Development Centre, Swedish University of Agricultural Sciences 24: 85-103.

6. Wardrop Engineers Inc (1988) Sokoto fadama shallow ground water study. Report submitted to the Sokoto Agricultural and Rural Development Authority. Sokoto State, Nigeria.

7. Owonubi JJ, Malgwi WB, Kparmwang T (1994) Utilisation and sustainability of fadama in northern Nigeria: Soil fertility and water conservation practices. In Kolawole A, Scoones I, Awogbade MO, Voh JP (Eds.), Strategies for the Sustainable Use of Fadama Lands in Northern Nigeria, CSER/IIED, Nigeria, pp 123-132.

8. Kolawole A (1993) Monitoring and evaluation of Nigeria's irrigation systems: the case of Bakolori Irrigation Project. Water Resources Development 9(1): 75-85.

9. Adams WM (1992) Wasting the Rain: Rivers, People and Planning in Africa, Earthscan, London, England.

10. Wakuti Consulting Engineers (1979) First Interim Report on the Zauro Polder Project. Wakuti Consulting Engineers, Kaduna, Nigeria.

11. Doran JW, Parkin TB (1994) Defining and assessing soil quality. In Doran JW, et al. (Eds.), Defining Soil Quality for Sustainable Environment. Soil Science Society of America, Inc. Madison, Wisconsin, pp. 3-21.

12. Doran JW (2002) Soil health and global sustainability: translating science into practice. Agriculture Ecosystems and Environment 88(2): 119-127.

13. Brejda JJ, Moorman TB, Karlen DL, Dao TH (2000) Identification of regional soil quality factors and indicators: I. Central and southern high plains. Soil Science Society of America Journal 64(6): 2115-2124.

14. Li Y, Lindstrom MJ (2001) Evaluating soil quality-soil redistribution relationship on terraces and steep hillslope. Soil Science Society of America Journal 65(5): 1500-1508.

15. Sun B, Zhou SL, Zhao QG (2003) Evaluation of spatial and temporal changes of soil quality based on geostatistical analysis in the hill region of subtropical China. Geoderma 115(1-2): 85-99. 
16. Shukla MK, Lal R, Ebinger M (2006) Determining soil quality indicators by factor analysis. Soil and Tillage Research 87(2): 194-204.

17. Velasquez E, Lavelle P, Andrade M (2007) GISQ, a multifunctional indicator of soil quality. Soil Biology and Biochemistry 39(12): 30663080.

18. Hussain I, Olson KR, Wander MM, Karlen DL (1999) Adaptation of soil quality indices and application to three tillage systems in Illinois. Soil and Tillage Research 50(3-4): 237-249.

19. Glover JD, Reganold JP, Andrews PK (2000) Systematic method for rating soil quality of conventional, organic, and integrated apple orchards in Washington State. Agriculture, Ecosystems and Environment 80(1-2): 29-45.

20. Andrews SS, Karlen DL, Mitchell JP (2002a) A comparison of soil quality indexing methods for vegetable production systems in northern California. Agriculture Ecosystems and Environment 90: 25-45.

21. Andrews SS, Mitchell JP, Mancineelli R, Karlen DL, Hartz TK, et al. (2002b) On-farm assessment of soil quality in California's central valley. Agronomy Journal 94: 12-23.

22. Andrews SS, Karlen DL, Cambardella CA (2004) The soil management assessment framework; A quantitative soil quality evaluation method. Soil Science Society of America 68: 1945-1962.

23. Masto RE, Chhonkar PK, Singh D, Patra AK (2007) Soil quality response to long-term nutrient and crop management on a semi-arid Inceptisol. Agriculture, Ecosystems and Environment 118(1-4): 130-142.

24. Xu M, Zhao Y, Liu G, Argent RM (2006) Soil quality indices and their application in the hilly loess plateau region of China. Australian Journal of Soil Research 44: 245-254.

25. Erkossa T, Itanna F, Stahr K (2007) Indexing soil quality: a new paradigm in soil science research. Australian Journal of Soil Research 45(2): 129-137.

26. Qi Y, Darilek JL, Huang B, Zhao Y, Sun W, et al. (2009) Evaluating soil quality indices in an agricultural region of Jiangsu Province. Geoderma 149(3-4): 325-334.

27. Karlen DL, Ditzler CA, Andrews SS (2003) Soil quality: why and how. Geoderma 114(3-4): 145-156.

28. FDALR (Federal Department of Agricultural Land Resources) (1990) Soil map of Nigeria with degradation interpretation. FAO/World Bank Cooperative Programme Investment Centre Report on Land Resources Management in Nigeria. Federal Department of Agricultural Land Resources, Abuja, Nigeria.

29. Oosterbaan RJ, Nijland HJ (1994) Determining the saturated hydraulic conductivity. In Ritzema HP (Ed.), Drainage Principles and Applications, ILRI Publication 16, second revised edition, Wageningen, The Netherlands, p. 1-40.

30. Grossman RB, Reinsch TG (2002) Bulk density and linear extensibility: Core method. In Dane JH, Topp GC (Eds.), Methods of Soil Analysis. Part 4. Physical Methods, American Society of Agronomy and Soil Science Society of America, Madison, Wisconsin, pp. 208-228.

31. Gee GW, Or D (2002) Particle-size analysis. In Dane JH, Topp GC (Eds.), Methods of Soil Analysis. Part 4. Physical Methods American Society of Agronomy and Soil Science Society of America, Madison, Wisconsin, pp. 255-294.

32. Nimmo JR, Perkins KS (2002) Aggregate stability and size distribution. In Dane JH, Topp GC (Eds.), Methods of Soil Analysis. Part 4. Physical Methods, American Society of Agronomy and Soil Science Society of America, Madison, Wisconsin, pp. 238-317.

33. Rhoades JD (1982a) Soluble salts. In Page AL, Miller RH, Keeney DR (Eds.), Methods of Soil Analysis Part 2. Chemical and Microbiological Properties, American Society of Agronomy and Soil Science Society of America, Madison, Wisconsin, pp. 167-179.
34. Thomas GW (1996) Soil pH and soil acidity. In Sparks DL (Ed.), Methods of Soil Analysis. Part 3. Chemical Methods Soil Science Society of America, Madison, WI, pp. 475-490.

35. Bremmer JM, Mulvaney CS (1982) Nitrogen - Total. In Page AL, Miller RH, Keeney DR (Eds.), Methods of Soil Analysis Part 2. Chemical and Microbiological Properties, Agronomy Monograph 9, American Society of Agronomy and Soil Science Society of America. Madison, Wisconsin, pp. 595-624.

36. Karlen DL, Stott DE (1994) A framework for evaluating physical and chemical indicators of soil quality. In Doran JW, Coleman DC, et al. (Eds.), Defining Soil Quality for a Sustainable Environment, SSSA Special Publication. 35, Soil Science Society of America, Madison, Wisconsin, pp. 53-72.

37. Abrol IP, Yadav JSP, Massoud FI (1988) Salt-Affected Soils and their Management. FAO Soils Bulletin 39. Food and Agriculture Organization of the United Nations, Rome, Italy.

38. Landon JR (1991) Booker Tropical Soil Manual. Longman Scientific and Technical, Essex, USA.

39. Enwezor WO, Ohiri AC, Opowaribo EE, Udo EJ (1990) A review of soil fertilizer use in crops in Southeastern zone of Nigeria. Federal Ministry of Agriculture and Natural Resources, Lagos, Nigeria.

40. Esu IE (1991) Detailed Soil Survey of NIHORT Farm at Bunkure, Kano State, Nigeria. Institute of Agricultural Research, Ahmadu Bello University, Zaria, Nigeria.

41. Curtin D, Naidu R (1998) Fertility constraints to plant production. In Sumner ME, Naidu R (Eds.), Sodic Soil: Distribution, Management and Environmental Consequences, Oxford University Press: New York, USA, pp. 107-123.

42. Esu IE (1982) Evaluation of soils for irrigation in the Kaduna area of Nigeria. Unpublished PhD Thesis, Ahmadu Bello University, Zaria, Nigeria.

43. Kparmwang T, Malgwi WB (1997) The genesis, classification and productivity limitations of sandstone soils in northwestern nigeria. In Singh BR (Eds.), management of Marginal Lands in Nigeria. Proceedings of the $23^{\text {rd }}$ Annual Conference of the Soil Science Society of Nigeria. Usmanu Danfodiyo University, Sokoto, Nigeria. pp 43-50.

44. Singh BR (1999a) Salinity/sodicity status of fadama soils in north western Nigeria. 1. Kebbi State. Nigerian Journal of Basic and Applied Science 8: 1-14.

45. Singh BR (1999b) Salinity/sodicity status of fadama soils in north western Nigeria. 2. Zamfara State. Nigerian Journal of Basic and Applied Science 8: 77-88.

46. Graham WBR (2000) Characteristics of the soils in the Birnin Kebbi area. 2. The soils of the Zauro Polder Pilot Irrigation Scheme. Nigerian Journal of Basic and Applied Sciences 9: 59-67.

47. Graham WBR (2004) Environmental Constraints to sustainable agriculture: A study of the soils of the Sokoto-Rima basin, northwestern Nigeria. International Journal of Environmental 2(1): 72-91.

48. Esu IE, Akpan-Idiok AU (2010) Morphology, physico-chemical properties and classification of alluvial soils in Adamawa State, Nigeria. Nigerian Journal of Soil Science 20(1): 15-26.

49. Chhabra R (1985) Crop response to phosphorus and potassium fertilization of a sodic soil. Agronomy Journal 77(5): 699-702.

50. Pearson CJ, Norman DW, Dixon J (1994) Sustainable Dryland Cropping In Relation to Soil Productivity. FAO Soils Bulletin 72, FAO, Rome, Italy.

51. Ozgoz E, Gunal H, Acir N, Gokmen F, Birol M, et al. (2011) Soil quality and spatial variability assessment of land use effects in a typic haplustoll. Land Degradation and Development 24(3): 277-286.

52. Brinkman R (1970) Ferrolysis, a hydromorphic soil forming process. Geoderma 3(3): 199-206. 
53. Ipinmidun WB (1970) The agricultural development of fadama with particular reference to Bomo fadama. Nigerian Agriculture Journal 7:152-163.

54. McIntyre DS (1958) Permeability measurement of soil crusts formed by raindrop impact. Soil Science 85(4): 185-189.

55. Moore DC, Singer MJ (1990) Crust formation effects on soil erosion processes. Soil Science Society of America Journal 54(4): 1117-1123.

56. Qadir M, Schubert S (2002) Degradation processes and nutrient constraints in sodic soils. Land Degradation and Development 13(4): 275-294.

57. Atkins International (2006) Nigeria Support to the Federal Ministry of Water Resources: Water Resources Management and Policy June 2006.

58. Bastida F, Zsolnay A, Hernández T, García C (2008) Past, present and future of soil quality indices: A biological perspective. Geoderma 147(3-4): 159-171.

59. Graham WBR (2009a) Environmental Problems of Northwestern Nigeria: An Agricultural Perspective1. A Review of the Current Status. The $2^{\text {nd }}$ National Engineering Conference, Waziri Umaru Federal Polytechnic, Birnin Kebbi, Nigeria.

60. Graham WBR (2009b) Environmental Problems of Northwestern Nigeria: An Agricultural Pespective. 2. A Review of Potentia Management Strategies. The $2^{\text {nd }}$ National Engineering Conference, Waziri Umaru Federal Polytechnic, Birnin Kebbi, Nigeria.

61. Kemper WD, Rosenau RC (1986) Aggregate stability and size distribution. (2 ${ }^{\text {nd }}$ Edn) In Klute A (Ed.) Methods of Soil Analysis Part I: Physical and Mineralogical Methods. 2nd Edition ASA, Inc., Madison, Wisconsin. p. 425-442.
62. Nelson DW, Sommers LE (1986) Total carbon, organic carbon, and organic matter. In Page AL, Miller RH, Keeney DR (Eds.), Methods of Soil Analysis Part 2. Chemical and Microbiological Properties, American Society of Agronomy and Soil Science Society of America, Madison, Wisconsin, pp. 539-573.

63. Olsen SR, Sommers LE (1982) Phosphorus. In Page AL, Miller RH, Keeney DR (Eds.), Methods of Soil Analysis Part 2. Chemical and Microbiological Properties, American Society of Agronomy and Soil Science Society of America, Madison, Wisconsin, pp. 403-430.

64. Oster JD, Shainberg I (2001) Soil responses to sodicity and salinity: Challenges and opportunities. Australian Journal of Soil Research 39(6): 1219-1224.

65. Rhoades JD (1982b) Cation exchange capacity. In Page AL, Miller RH, Keeney DR (Eds.), Methods of Soil Analysis Part 2. Chemical and Microbiological Properties, American Society of Agronomy and Soil Science Society of America, Madison, Wisconsin, pp. 149-157.

66. Soil Survey Division Staff (1993) Soil Survey Manual. Soil Conservation Service. US Department of Agriculture Handbook 18. United States Department of Agriculture, US Government Printing Office, Washington, USA.

67. Thomas GW (1982) Exchangeable cations. In Page AL, Miller RH, Keeney DR (Eds.), Methods of Soil Analysis Part 2. Chemical and Microbiological Properties, American Society of Agronomy and Soil Science Society of America, Madison, Wisconsin, pp. 159-165.

68. US Salinty Laboratory Staff (1954) Diagnosis and Improvement of Saline and Alkali Soils. Richards LA (Ed.), Agriculture Handbook No. 60, United States Department of Agriculture, US Government Printing Office, Washington DC, USA, pp. 1-166.

\section{Your next submission with Juniper Publishers will reach you the below assets}

- Quality Editorial service

- Swift Peer Review

- Reprints availability

- E-prints Service

- Manuscript Podcast for convenient understanding

- Global attainment for your research

- Manuscript accessibility in different formats ( Pdf, E-pub, Full Text, Audio)

- Unceasing customer service

Track the below URL for one-step submission https://juniperpublishers.com/online-submission.php 